Przybyła J., Bręborowicz M., Bręborowicz E., Lubiatowski P., Romanowski L. Shoulder isokinetic profile in young nonathletes Shoulder isokinetic profile in young nonathletes. Issue Rehabil. Orthop. Neurophysiol. Sport Promot. 2016; 16: 23-39.

\section{SHOULDER ISOKINETIC PROFILE IN YOUNG NONATHLETES}

Jakub Przybyła

Maciej Bręborowicz

Ewa Bręborowicz

Przemysław Lubiatowski

Leszek Romanowski

Department and Clinic of Orthopaedics, Traumatology and Hand Surgery, Poznań University of Medical Sciences, Poznań, Poland

\section{SUMMARY}

\section{Introduction}

The glenohumeral joint is one of the most complex joints of human body. It allows one to perform complex movements in all planes. In the literature there are few studies on the shoulder isokinetics in nonathletes. Usually, the research would concern the throwing shoulder in young athletes.

\section{Aim}

The aim of the study was to define the isokinetic profile of the shoulder in external and internal rotation in nonathletes. These persons were chosen among students with an average fitness level, with no injuries in upper extremities, so could be assumed as a representative trial in population. We were aware of the fact that our group had a limited number but research in commonly accepted papers devoted to shoulder isokinetics had been performed using a similar number of volunteers.

\section{Material and methods}

Thirty volunteers with healthy shoulders (16 women and 14 men, age 20-25 years) have been tested using Biodex ${ }^{\circledR}$ dynamometer.
PROFIL IZOKINETYCZNY STAWU RAMIENNEGO U MŁODYCH OSÓB NIE UPRAWIAJĄCYCH SPORTU

Jakub Przybyła

Maciej Bręborowicz

Ewa Bręborowicz

Przemysław Lubiatowski

Leszek Romanowski

Katedra i Klinika Ortopedii, Traumatologii i Chirurgii Ręki, Uniwersytet Medyczny im. Karola Marcinkowskiego w Poznaniu, Polska

\section{STRESZCZENIE}

Wstęp

Staw ramienny jest jedną z najbardziej skomplikowanych struktur ludzkiego organizmu. Umożliwia wykonywanie złożonych ruchów we wszystkich płaszczyznach. W literaturze światowej niewiele jest opracowań dotyczących izokinetyki stawu ramiennego u osób nietrenujących wyczynowo. Zazwyczaj badano właściwości barku w trakcie rzutu u młodych sportowców.

\section{Cel pracy}

Celem przeprowadzonego badania było określenie profilu izokinetycznego stawu ramiennego $\mathrm{w}$ rotacji zewnętrznej i wewnętrznej u osób nie uprawiających sportu. Osoby te były rekrutowane wśród studentów o przeciętnej sprawności fizycznej, bez żadnych urazów kończyn górnych, a więc mogą być uznane za próbę reprezentatywną populacji. Zdajemy sobie sprawę z tego, że nasza grupa ma ograniczoną liczebność, jednakże badania w pracach poświęconych izokinetyce barku, które sa powszechnie uznawane za badania wzorcowe, wykonywano na podobnej liczbie osób.

\section{Materiał i metody}

W badaniu wzięło udział 30 ochotników w wieku od 20 do 25 lat - 16 kobiet i 14 mężczyzn. Do zebrania danych izokinetycznych 
Internal and external rotation of the shoulder at $90^{\circ} / \mathrm{sec}$ ( $3 \mathrm{reps}$ ), $180^{\circ} / \mathrm{sec}$ ( $3 \mathrm{reps}$ ), $270^{\circ} \%$ sec (15 reps), $360^{\circ} / \mathrm{sec}$ ( 3 reps) angular speeds were tested.

\section{Results}

In statistical analysis peak torque, average power, total work and agonist-antagonist ratio were taken into consideration.

The mean value of muscle peak torque for the dominant extremity in external rotation at $90 \%$ sec. angular speed was $20.6 \mathrm{~J}$ and in internal rotation it was $30.3 \mathrm{~J}$. For the non-dominant extremity the mean value of muscle peak torque in external rotation at $90 \% \mathrm{sec}$. the angular speed was $19.0 \mathrm{~J}$ and in internal rotation it was $28.4 \mathrm{~J}$.

The mean muscle total work in dominant extremity's external rotation at $270^{\circ} / \mathrm{sec}$. the angular speed (the largest number of repetitions per serie) was $246.1 \mathrm{~J}$ and in internal rotation it was $407.4 \mathrm{~J}$. For the non-dominant extremity the mean muscle total work in external rotation was $203.4 \mathrm{~J}$ and for the external rotation it was $374.1 \mathrm{~J}$.

Muscle average power for the dominant extremity in external rotation and at $270^{\circ} \%$ sec. the angular speed was $27.0 \mathrm{~W}$ and in internal rotation it was $44.0 \mathrm{~W}$. For the non-dominant extremity, muscle average power in external rotation was $21.5 \mathrm{~W}$ and in internal rotation it was $40.1 \mathrm{~W}$. posłużono się systemem dynamometrycznym Biodex Multijoint System Pro 4. Zbadano właściwości izokinetyczne stawu ramiennego dla prędkości kątowych: $90^{\circ}$ \% sek. (3 powtórzenia w serii), $180^{\circ} /$ sek. (3 powtórzenia w serii), $270 \%$ sek. (15 powtórzeń w serii) i $360 \%$ sek. (3 powtórzenia w serii).

\section{Wyniki}

W analizie statystycznej wzięto pod uwagę następujące parametry izokinetyczne: szczytowy moment siły mięśni, średnią moc mięśni, całkowitą prace mięśni i stosunek reciprokalnych grup mięśniowych.

Średnia wartość szczytowego momentu siły mięśni dla strony dominującej w rotacji zewnętrznej i prędkości kątowej 90\% sek. wyniosła 20,6 J, natomiast w rotacji wewnętrznej średnia wartość szczytowego momentu siły wyniosła 30,3 J. Dla strony niedominującej w rotacji zewnętrznej i prędkości kątowej $90^{\circ}$ sek. średnia wartość szczytowego momentu siły mięśniowej wyniosła 19,0 J, a w rotacji wewnętrznej średnia wartość szczytowego momentu siły mięśniowej wyniosła 28,4 J.

Średnia wartość całkowitej pracy mięśni dla rotacji zewnętrznej strony dominującej i prędkości kątowej 270\%/sek. (najwięcej powtórzeń) wyniosła 246,1 J, natomiast dla rotacji wewnętrznej 407,4 J. Dla strony niedominującej średnia wartość całkowitej pracy mięśni przy tej samej prędkości kątowej i rotacji zewnętrznej wyniosła 203,4 J, a dla rotacji wewnętrznej 374,1 J.

Średnia moc mięśni dla strony dominującej w rotacji zewnętrznej i prędkości kątowej $270^{\circ}$ sek. wyniosła $27,0 \mathrm{~W}$, a w rotacji wewnętrznej 44,0 W. Dla strony niedominującej w rotacji zewnętrznej i tej samej prędkości średnia moc mięśni wyniosła 21,5 W, a w rotacji wewnętrznej 40,1 W. 


\section{Conclusions}

The results have shown that all parameters were higher in dominant extremities in comparison to the non-dominant. Muscle peak torque, power and work were higher in internal rotation than in external rotation. Agonist-antagonist ratio of internal to external rotators was within the range of $68.8 \%-85.8 \%$ and was higher in dominant extremity. The results were coherent with those obtained by other researchers and can be used as auxiliary data in further shoulder joint isokinetics research.

Keywords: shoulder, isokinetic profile, external rotation, internal rotation

Date received: June 10th 2016

Date accepted: July 7th 2016

\section{Introduction}

The glenohumeral joint is one of the most complex joints of human body. It allows one to perform complex movements in all planes. Despite the extremely complicated structure (and thus many factors that determine its effectiveness) it retains some invariable biomechanical properties. Any differences may result from injuries or sports in which the phenomenon of "specialization" of dominant extremity takes place. This is demonstrated by isokinetic testing conducted by many researchers, such as Hughes et al., Cook et al, Hinton, Ivey et al, Malerba, Alderink and Kuck and Wilk et al. (Ivey et al. 1985; Alderink and Kuck 1986; Cook et al. 1987; Hinton 1988; Malerba et al. 1993; Wilk et al. 1993; Hughes et al. 1999).

Isokinetics can be defined as a movement at a constant velocity which is ascertained by special devices (Eliasz et al. 1994).

\section{Wnioski}

Szczytowy moment siły mięśni strony dominującej jest wyższy niż strony niedominującej i jest on zawsze wyższy dla rotatorów wewnętrznych; wartość średniej mocy i całkowitej pracy mięśni w rotacji zewnętrznej są zawsze większe po stronie dominującej w porównaniu ze stroną niedominującą. Stosunek reciprokalnych grup mięśniowych rotatorów wewnętrznych i zewnętrznych zawierał się w granicach $68,8 \%-85,8 \%$ i był wyższy dla kończyny dominującej. Wyniki mogą być użyteczne z punktu widzenia dalszych badań, jako dane normatywne dotyczące parametrów zdrowych stawów ramiennych osób nie uprawiających sportu wyczynowego.

Słowa kluczowe: staw ramienny, profil izokinetyczny, rotacja zewnętrzna, rotacja wewnętrzna

Data otrzymania:10 czerwiec 2016

Data zaakceptowania: 7 lipiec 2016

\section{Wstęp}

Staw ramienny jest jedną z najbardziej skomplikowanych struktur ludzkiego organizmu. Umożliwia wykonywanie złożonych ruchów we wszystkich płaszczyznach. Pomimo niezwykle skomplikowanej budowy (a więc i wielu czynników, od których zależy jego działanie) zachowuje pewne stałe właściwości biomechaniczne. Ewentualne różnice mogą wynikać z przebytych uszkodzeń lub uprawiania sportu, w którym zachodzi zjawisko „specjalizacji” dominującej w danej dyscyplinie sportu kończyny. Dowodzą tego badania izokinetyczne wielu naukowców, takich jak Hughes i wsp., Cook i wsp., Hinton, Ivey i wsp., Malerba, Alderink i Cook oraz Wilk i wsp. (Ivey i wsp. 1985; Alderink i Kuck 1986; Cook i wsp. 1987; Hinton 1988; Malerba i wsp. 1993; Wilk i wsp. 1993; Hughes i wsp. 1999).

Pojęcie izokinetyki definiuje się jako ruch o stałej prędkości, która kontrolowana jest poprzez użycie odpowiednich do 
Isokinetic training concept was created and developed by Perrine and Hislop in the 1960's and since then its popularity is constantly increasing (Hislop and Perrine 1967). Isokinetic assessment allows to perform an unbiased verification of rehabilitation progress after injuries or effects of the rehabilitation process after injuries or reconstruction of the injured movement system but only in few studies the informai tion about isokinetics of healthy shoulders can be found (Ivey et al. 1985; Ellenbecker and Derscheid 1989; Basset et al. 1990; Ellenbecker and Bleacher 1999; Hughes et al. 1999; Ellenbecker and Davies 2000; Biodex Multijoint System Pro Setup).

In the literature there are few studies on the shoulder isokinetics in nonathletes (Hughes et al. 1999; Ellenbecker and Bleacher 1999). Usually, the research would concern the throwing shoulder in young athletes (Brown et al. 1988; Ellenbecker 1991; Chandler et al. 1992; Ellenbecker 1992; Ellenbecker and Mattalino 1997).

\section{Aim \\ The aim of the study was to define the isokinetic profile of the shoulder in external and internal rotation in nonathletes. These persons were chosen among students with an average fitness level, with no injuries in upper extremities, so it could be assumed as a representative trial in population. We were aware of the fact that our group had a limited number but research in commonly accepted papers devoted to shoulder isoki- netics had been performed using a similar number of volunteers.}

\section{Material and methods}

The study involved 30 healthy volunteers with no shoulder pathology aged from 20 tego celu urządzeń (Eliasz i wsp. 1994). Koncepcja treningu izokinetycznego stworzona została przez Perrine'a i Hislopa w latach 60-tych XX wieku i od tego czasu zyskuje na popularności (Hislop i Perrine 1967). Badania izokinetyczne pozwalają na obiektywną ocenę procesu rehabilitacji po urazach lub efektów rehabilitacji po rekonstrukcji uszkodzonego aparatu ruchu, ale tylko w nielicznych publikacjach mowa jest o właściwościach izokinetycznych nieuszkodzonego stawu ramiennego (Ivey i wsp. 1985; Ellenbecker i Derscheid 1989; Basset i wsp. 1990; Ellenbecker i Bleacher 1999; Hughes i wsp. 1999; Ellenbecker i Davies 2000; Biodex Multijoint System Pro Setup).

W literaturze światowej niewiele jest opracowań dotyczących izokinetyki stawu ramiennego u osób nietrenujących wyczynowo (Hughes i wsp. 1999; Ellenbecker i Bleacher 1999). Zazwyczaj badano właściwości barku rzucającego u młodych sportowców (Brown i wsp. 1988; Ellenbecker 1991; Chandler i wsp. 1992; Ellenbecker 1992; Ellenbecker i Mattalino 1997).

\section{Cel pracy}

Celem przeprowadzonego badania było określenie profilu izokinetycznego stawu ramiennego $\mathrm{w}$ rotacji zewnętrznej i wewnętrznej. Badaliśmy tylko osoby młode, nietrenujące, co jest uwzględnione w tytule pracy. Osoby te były rekrutowane wśród studentów o przeciętnej sprawności fizycznej, bez żadnych urazów kończyn górnych, a więc mogą być uznane za próbę reprezentatywną populacji. Oczywiście zdajemy sobie sprawę z tego, że nasza grupa ma ograniczoną liczebność, jednakże badania w pracach poświęconych izokinetyce barku, które sa powszechnie uznawane za wzorcowe, wykonywano na podobnej liczbie osób.

\section{Materiał i metody}

W badaniu wzięło udział 30 ochotników w wieku od 20 do 25 lat -16 kobiet i 14 
to 25 years -16 women and 14 men. Every volunteer agreed for the evaluation. Detailed properties of the control group are listed in Table 1 below.

Table 1. Control group parameters.

\begin{tabular}{lllllll} 
& \multicolumn{2}{c}{ Males } & \multicolumn{2}{c}{ Females } & \multicolumn{2}{c}{ Total } \\
\hline & Mean & SD & Mean & SD & Mean & SD \\
\hline Age & $\mathbf{2 1 . 9}$ & $\mathbf{1 . 5}$ & $\mathbf{2 1 . 2}$ & $\mathbf{0 . 7}$ & $\mathbf{2 2 . 2}$ & 1.2 \\
Height & 168.4 & 6.1 & 156.1 & 7.0 & 167.1 & 9.8 \\
Weight & 73.7 & 11.1 & 55.4 & 4.1 & 66.1 & 12.9
\end{tabular}

Study participants were qualified for the study based on the following criteria: normal shoulder function without any pain or discomfort (based on clinical evaluation and shoulder questionnaire), age 20-25, a written consent to participate in the study.

Candidates would be excluded from participation if practicing professional sports (currently or in the past), had a history of injury or disease of the shoulder, structural shoulder pathology on ultrasound scan any disorder within cervical spine, any general chronic disorder (cardiac, pulmonary, neurologic, metabolic etc.).

All participants were informed about the purpose and study procedures and signed a written consent. Project had permission of Bioethics Committee of Poznan University of Medical Sciences. Tests were performed using a BIODEX ${ }^{\circledR}$ Multi-Joint System 4 Pro dynamometer.

Every examination was performed in a modified neutral seated position. It is much used position for isokinetic internal-external rotation examinations of the glenohumeral joint (Ellenbecker and Davies 2000; Quincy et al. 2000). Davies termed it the $30^{\circ} / 30^{\circ} / 30^{\circ}$ position (Davies 1992 ). The glenohumeral joint is placed in 30-degree abduction, 30-degree forward flexion mężczyzn. Szczegółowe parametry grupy kontrolnej ujęto w Tabeli 1.

Tabela 1. Parametry grupy kontrolnej.

\begin{tabular}{lllllll} 
& \multicolumn{2}{c}{ Mężczýni } & \multicolumn{2}{c}{ Kobiety } & \multicolumn{2}{c}{ Ogółem } \\
\hline & Średnia & SD & Średnia & SD & Średnia & SD \\
\hline Wiek & $\mathbf{2 1 , 9}$ & $\mathbf{1 , 5}$ & $\mathbf{2 1 , 2}$ & $\mathbf{0 , 7}$ & $\mathbf{2 2 , 2}$ & 1,2 \\
Wzrost & 168,4 & 6,1 & 156,1 & 7,0 & 167,1 & 9,8 \\
Masa ciała & 73,7 & 11,1 & 55,4 & 4,1 & 66,1 & 12,9
\end{tabular}

Warunkami koniecznymi uprawniającymi do badania były: prawidłowe funkcjonowanie stawu ramiennego bez jakiegokolwiek bólu lub innych dolegliwości (w oparciu o ocenę kliniczną i kwestionariusz wypełniony przez ochotnika), wiek 20-25 lat, pisemna zgoda na udział w badaniach.

Kryteria wykluczające kandydatów z badań to: uprawianie $\mathrm{w}$ przeszłości lub na dzień przeprowadzania badania sportów wyczynowych, przebyte kontuzje lub stany zapalne w obrębie stawu ramiennego, zaburzenia strukturalne stawu ramiennego w badaniu ultrasonograficznym, jakiekolwiek zaburzenia w ramach kręgosłupa szyjnego, wystąpienie jakiejkolwiek przewlekłej choroby (serca, płuc, chorób neurologicznych, metabolicznych itp.).

Każdy z uczestników badania został poinformowany o celu i procedurach badania oraz podpisał pisemną zgodę na udział w badaniach. Projekt uzyskał zgodę Komitetu Bioetycznego Uniwersytetu Medycznego w Poznaniu. Badania wykonano na dynamometrze BIODEX ${ }^{\circledR}$ Multi-Joint System 4 Pro.

Każde badanie wykonywano w pozycji siedzącej zmodyfikowanej (zmodyfikowanej neutralnej). Jest to najpopularniejsza pozycja do badań izokinetyki stawu ramiennego w rotacji wewnętrznej i zewnętrznej (Ellenbecker i Davies 2000; Quincy i wsp. 2000). Davies określił ją mianem pozycji $30^{\circ} / 30^{\circ} / 30^{\circ}$, ponieważ staw ramienny osoby badanej ustawiony jest w 30 -stopniowym 
into the plane of the scapula and the dynamometer is in 30-degree diagonal tilt from the transverse plane (Davies 1992).

The dynamometer was configured according to recommendations of the producer, that were as follows (Biodex Multijoint System Pro Operation Manual):

- rotation of the dynamometer: $20^{\circ}$

- dynamometer tilt: $50^{\circ}$

- direction of the seat: $0^{\circ}$

- initial position: maximal internal rotation

The procedure preparing for examination was similar for both dominant and non-dominant side and could be divided into the following steps:

- seating the patient and turnover of the column with the armchair to $0^{\circ}$ position

- turnover of the column with the dynamometer to $20^{\circ}$ position in the horizontal plane

- tilting the dynamometer to $50^{\circ}$ position in the vertical plane

- attaching the glenohumeral joint handle

- placing the seat with the patient in the distance appropriate to dynamometer

- stabilization of the patient by fastening 4-point belts

After the patient was seated the essential pieces of information were collected: full name, date of birth, height, body weight, extremity dominance (right- and left-handed). After that, a testing protocol was chon sen (described below) and the range of movement in which the protocol was supposed to be undergone was set.

The research protocol was divided into four series with different angular speeds and number of repetitions. In the first series, 3 repetitions were performed for internal and external rotation at the speed of $180^{\circ} / \mathrm{sec}$. In the second series, 3 repetitions were performed for internal and odwiedzeniu, 30-stopniowym uniesieniu w płaszczyźnie łopatki oraz 30 stopniowym wysunięciu do przodu (Davies 1992).

Dynamometr skonfigurowano zgodnie z zaleceniami producenta, a więc (Biodex Multijoint System Pro 4 Operation Manual):

- rotacja dynamometru: $20^{\circ}$

- wychylenie dynamometru: $50^{\circ}$

- kierunek siedziska: $0^{\circ}$

- pozycja początkowa: maksymalna rotacja wewnętrzna

Procedura przygotowania do badania była podobna dla strony dominującej i niedominującej I dzieliła się na następujące kroki:

- usadzenie pacjenta w fotelu podłączonym do aparatury i obrót kolumny z fotelem do pozycji $0^{\circ}$

- obrót kolumny z częścią dynamometryczną urządzenia do pozycji $20^{\circ} \mathrm{W}$ płaszczyźnie poziomej

- przechylenie dynamometru do pozycji $50^{\circ} \mathrm{w}$ płaszczyźnie pionowej

- zamocowanie przystawki stawu ramiennego

- ustawienie siedziska z pacjentem w odległości właściwej do wykonania dalszych kroków

- stabilizacja pacjenta poprzez zapięcie pasów 4-punktowych

Po usadzeniu pacjenta, uzyskano niezbędne informacje: imię i nazwisko, datę urodzenia, wzrost, masę ciała, określono dominację kończyn (prawo- lub leworęczność). Następnie wybrano zaprogramowany wcześniej protokół badań i określono zakres ruchu, w ramach którego wykonane miało być badanie.

Protokół badań był podzielony na cztery serie o różnej ilości powtórzeń i prędkości kątowej. W pierwszej serii wykonywano po 3 powtórzenia dla rotacji wewnętrznej i zewnętrznej z prędkością $180^{\circ}$ s, w drugiej po 3 powtórzenia z prędkością $90 \%$, w trzeciej po 3 powtórzenia z prędkością 
external rotation at the angular speed of $90 \%$ sec., in the third series, 3 repetitions were performed for internal and external rotation at the speed of $360 \% \mathrm{sec}$. and in the fourth series, unlike in previous series, 15 repetitions were performed for internal and external rotation at the speed of $270^{\circ} \%$ sec. During the series, the patient was motivated to maximum commitment with verbal commands. A 30-second pause between the series was set.

The following isokinetic parameters were collected: agonist-antagonist ratio (indicates how muscles around the joint affect each other), peak torque (the highest muscle force output during a repetition), tot tal work (the amount of work performed during a series) and average power (total power in a series divided by time required to complete a series).

In order to calculate statistical significance, T-Test was chosen.

\section{Results}

The findings are included in the following tables divided in accordance to the assessed parameter.

\section{Peak torque}

The examination showed a significant differh ence between dominant and non-dominant limbs in peak torque in external rotation for the $270^{\circ} / \mathrm{sec}$. and $360^{\circ} / \mathrm{sec}$. velocities. No significant differences were showed for the other series.

The results are summarized in Table 2. $360^{\circ}$ s i w czwartej po 15 powtórzeń z prędkością $270^{\circ}$ s. Rozpoczęcie i zakończenie serii sygnalizował komunikat dźwiękowy. Ustalono 30-sekundową przerwę między seriami. W trakcie ćwiczeń pacjenta motywowano do maksymalnego zaangażowania komendami słownymi oraz poprzez wizualizację postępu ćwiczeń na ekranie komputera.

Uzyskano dane dotyczące następujących parametrów izokinetycznych: szczytowy moment siły mięśni (muscle peak torque) określa maksymalną siłę mieśni uzyskaną w danej serii, stosunek reciprokalnych grup mięśniowych (agonist-antagonist ratio) opisujący, jak oddziałują na siebie mięśnie otaczające staw, całkowita praca mięśni (total work) - ilość pracy wykonanej podczas serii oraz średnia moc mięśni (average power) - iloraz całkowitej mocy mięśni i czasu potrzebnego na ukończenie serii.

Do oceny istotności statystycznej posłużono się testem T-Studenta.

\section{Wyniki}

Wyniki badań zawarto w poniższych tabelach z podziałem według badanego parametru.

Szczytowy moment sity mięśni (muscle peak torque)

Badanie wykazało istotną różnicę w szczytowym momencie siły mięśni $\mathrm{w}$ rotacji zewnętrznej dla prędkości $270^{\circ}(0,021)$ i w rotacji zewnętrznej dla prędkości $360^{\circ}$ $(0,018)$. Nie wykazano istotnych różnic dla pozostałych parametrów.

Z pomiarów wynika, że osiągnięty szczytowy moment siły mięśni był większy dla strony dominujaccej we wszystkich prędkościach kątowych bez względu na ilość powtórzeń. Widoczny jest również większy moment siły mięśni dla rotacji wewnętrznej niż zewnętrznej. Wyniki podsumowano w Tabeli 2. 
Table 2. Results for peak torque of dominant and non-dominant limb.

\begin{tabular}{|c|c|c|c|c|c|c|}
\hline \multicolumn{2}{|c|}{ Movement } & \multicolumn{2}{|c|}{ Dominant } & \multicolumn{2}{|c|}{ Non-dominant } & \multirow{2}{*}{$\begin{array}{c}\begin{array}{c}\text { Statistical } \\
\text { significance }\end{array} \\
\mathrm{P}-\text { value } \\
\end{array}$} \\
\hline & & Mean & SD & Mean & SD & \\
\hline \multirow{2}{*}{$90 \% / \mathrm{s} 3 \#$} & Ext. rot. & 20.6 & 7.3 & 19.0 & 6.3 & 0.1 \\
\hline & Int. rot. & 30.3 & 12.4 & 28.4 & 10.7 & 0.1 \\
\hline \multirow{2}{*}{$180^{\circ} / \mathrm{s} 3 \#$} & Ext. rot. & 20.8 & 6.9 & 19.6 & 7.5 & 0.1 \\
\hline & Int. rot. & 26.2 & 12.0 & 25.8 & 12.5 & 0.8 \\
\hline \multirow{2}{*}{$270 \%$ s 15\# } & Ext. rot. & 23.4 & 7.5 & 20.9 & 7.7 & $0.0^{*}$ \\
\hline & Int. rot. & 30.6 & 11.3 & 29.0 & 11.0 & 0.2 \\
\hline \multirow{2}{*}{$360^{\circ} / \mathrm{s} 3 \#$} & Ext. rot. & 23.3 & 9.5 & 20.8 & 9.3 & $0.0^{*}$ \\
\hline & Int. rot. & 30.4 & 12.7 & 29.7 & 11.6 & 0.6 \\
\hline
\end{tabular}

Tabela 2. Wyniki uzyskane dla szczytowego momentu siły mięśni kończyny dominującej i niedominującej.

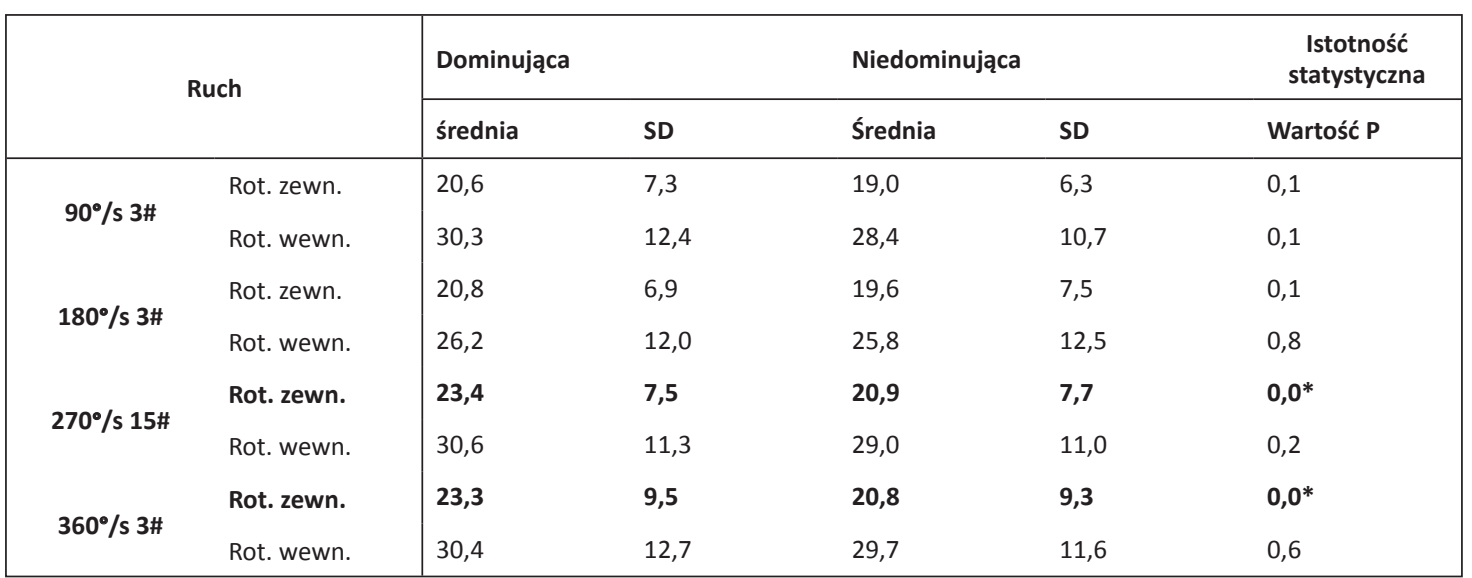

\section{Total work}

The examination showed significantly higher results in muscle total work for external rotation in the dominant in comparison to non-dominant extremity at all velocities.

Greater amount of work, in comparison to other velocities, was done at the angular speed of $270^{\circ} / \mathrm{sec}$. The reason for such result was that in this series of movements volunteers performed 15 repetitions instead of 3 as in other series.

Irrespective of the angular speed and the number of repetitions in a series, muscles performed larger amount of work in internal rather than external rotation (Table 3 ).
Całkowita praca miesśni (muscle total work) Badanie wykazało znacznie wyższe wyniki w całkowitej pracy mięśni dla rotacji zewnętrznej w porównaniu do rotacji wewnętrznej przy wszystkich prędkościach kątowych.

Większa praca, w porównaniu do innych prędkości, wykonana została przy powtórzeniach z prędkością kątową wynoszącą $270 \%$ sek. Jest to spowodowane większą ilością powtórzeń w serii - badani wykonali 15 zamiast 3 powtórzeń, jak w innych seriach.

Bez względu na prędkość kątową i ilość powtórzeń w serii, mięśnie wykonały większą pracę $\mathrm{w}$ rotacji wewnętrznej niż zewnętrznej (Tabela 3). 
Table 3. Results for total work of dominant and non-dominant limb.

\begin{tabular}{|c|c|c|c|c|c|c|}
\hline \multicolumn{2}{|c|}{ Movement } & \multicolumn{2}{|c|}{ Dominant } & \multicolumn{2}{|c|}{ Non-dominant } & \multirow{2}{*}{$\begin{array}{c}\begin{array}{c}\text { Statistical } \\
\text { significance }\end{array} \\
\mathrm{P}-\text { value }\end{array}$} \\
\hline & & Mean & SD & Mean & SD & \\
\hline \multirow{2}{*}{$90 \% / \mathrm{s} 3 \#$} & Ext. rot. & 72.4 & 29.7 & 61.0 & 24.8 & $0.0 * *$ \\
\hline & Int. rot. & 113.1 & 45.8 & 104.6 & 38.4 & 0.1 \\
\hline \multirow{2}{*}{$180^{\circ} / \mathrm{s} 3 \#$} & Ext. rot. & 54.4 & 24.3 & 46.9 & 22.8 & $0.0 * *$ \\
\hline & Int. rot. & 84.2 & 44.1 & 78.6 & 41.3 & 0.2 \\
\hline \multirow{2}{*}{$270^{\circ} / \mathrm{s} 15 \#$} & Ext. rot. & 246.1 & 107.1 & 203.4 & 89.6 & $0.0 * *$ \\
\hline & Int. rot. & 407.4 & 206.6 & 374.1 & 171.3 & 0.2 \\
\hline \multirow{2}{*}{$360^{\circ} / \mathrm{s} 3 \#$} & Ext. rot. & 51.0 & 20.5 & 45.8 & 20.6 & $0.0 *$ \\
\hline & Int. rot. & 81.2 & 38.8 & 75.8 & 33.3 & 0.2 \\
\hline
\end{tabular}

Tabela 3. Wyniki uzyskane dla całkowitej pracy mięśni kończyny dominującej i niedominującej.

\begin{tabular}{|c|c|c|c|c|c|c|}
\hline & \multirow[t]{2}{*}{ Ruch } & \multicolumn{2}{|c|}{ Dominująca } & \multicolumn{2}{|c|}{ Niedominująca } & \multirow{2}{*}{$\begin{array}{c}\begin{array}{c}\text { Istotność } \\
\text { statystyczna }\end{array} \\
\text { Wartość P }\end{array}$} \\
\hline & & średnia & SD & Średnia & SD & \\
\hline \multirow{2}{*}{$90 \% / \mathrm{s} 3 \#$} & Rot. zewn. & 72,4 & 29,7 & 61,0 & 24,8 & $0,0 * *$ \\
\hline & Rot. wewn. & 113,1 & 45,8 & 104,6 & 38,4 & 0,1 \\
\hline \multirow{2}{*}{$180^{\circ} / \mathrm{s} 3 \#$} & Rot. zewn. & 54,4 & 24,3 & 46,9 & 22,8 & $0,0 * *$ \\
\hline & Rot. wewn. & 84,2 & 44,1 & 78,6 & 41,3 & 0,2 \\
\hline \multirow{2}{*}{$270^{\circ} / \mathrm{s} 15 \#$} & Rot. zewn. & 246,1 & 107,1 & 203,4 & 89,6 & $0,0 * *$ \\
\hline & Rot. wewn. & 407,4 & 206,6 & 374,1 & 171,3 & 0,2 \\
\hline \multirow{2}{*}{$360^{\circ} / \mathrm{s} 3 \#$} & Rot. zewn. & 51,0 & 20,5 & 45,8 & 20,6 & $0,0^{*}$ \\
\hline & Rot. wewn. & 81,2 & 38,8 & 75,8 & 33,3 & 0,2 \\
\hline
\end{tabular}

\section{Average power}

The examination showed significantly higher results in muscle average power for external rotation of the dominant in comparison to non-dominant limb at all speeds, irrespective of the number of repetitions per series (Table 4).
Średnia moc mięśni (average power)

Badanie wykazało istotną różnicę w średniej mocy mięśni dla rotacji zewnętrznej we wszystkich prędkościach, bez względu na ilość powtórzeń w serii.

Dla rotacji zewnętrznej z prędkością $90 \%$ wykazano różnicę o bardzo wysokiej istotności ( $\mathrm{p}<0,0001)$, a dla rotacji zewnętrznej z prędkością $180^{\circ}$ s wykazano różnicę o bardzo wysokiej istotności $(\mathrm{p}<0,005)$. Dla rotacji zewnętrznej z prędkością $270^{\circ}$ s wykazano różnicę o bardzo wysokiej istotności $(\mathrm{p}<0,001)$, a dla rotacji zewnętrznej z prędkością $360 \%$ s wykazano różnicę o wysokiej istotności $(\mathrm{p}<0,05)$.

We wszystkich prędkościach, bez względu na ilość powtórzeń wykazano, że średnia moc mięśni strony dominującej była większa od średniej mocy mięśni strony niedominującej (Tabela 4). 
SHOULDER ISOKINETIC PROFILE IN YOUNG NONATHLETES

Table 4. Results for average power of dominant and non-dominant limb.

\begin{tabular}{|c|c|c|c|c|c|c|}
\hline \multicolumn{2}{|c|}{ Movement } & \multicolumn{2}{|c|}{ Dominant } & \multicolumn{2}{|c|}{ Non-dominant } & \multirow{2}{*}{$\begin{array}{l}\begin{array}{l}\text { Statistical } \\
\text { significance }\end{array} \\
\text { P - value }\end{array}$} \\
\hline & & Mean & SD & Mean & SD & \\
\hline \multirow{2}{*}{$90^{\circ} / \mathrm{s} 3 \#$} & Ext. rot. & 20.7 & 8.5 & 17.7 & 8.4 & $0.0^{* *}$ \\
\hline & Int. rot. & 31.7 & 13.0 & 30.1 & 12.4 & 0.2 \\
\hline \multirow{2}{*}{$180^{\circ} / \mathrm{s} 3 \#$} & Ext. rot. & 24.4 & 12.8 & 20.9 & 12.6 & $0.0 * *$ \\
\hline & Int. rot. & 37.3 & 21.7 & 34.5 & 21.2 & 0.3 \\
\hline \multirow{2}{*}{$270 \%$ s 15\# } & Ext. rot. & 27.0 & 15.3 & 21.5 & 13.1 & $0.0 * *$ \\
\hline & Int. rot. & 44.0 & 26.2 & 40.1 & 22.0 & 0.2 \\
\hline \multirow{2}{*}{$360^{\circ} / \mathrm{s} 3 \#$} & Ext. rot. & 28.6 & 16.0 & 25.1 & 15.8 & $0.0^{*}$ \\
\hline & Int. rot. & 43.5 & 26.9 & 42.6 & 26.3 & 0.8 \\
\hline
\end{tabular}

Tabela 4. Wyniki uzyskane dla średniej mocy mięśni kończyny dominującej i niedominującej.

\begin{tabular}{|c|c|c|c|c|c|c|}
\hline \multirow{2}{*}{\multicolumn{2}{|c|}{ Ruch }} & \multicolumn{2}{|c|}{ Dominująca } & \multicolumn{2}{|c|}{ Niedominująca } & \multirow{2}{*}{$\begin{array}{l}\begin{array}{l}\text { Istotność } \\
\text { statystyczna }\end{array} \\
\text { Wartość P }\end{array}$} \\
\hline & & Średnia & SD & Średnia & SD & \\
\hline \multirow{2}{*}{$90 \% / \mathrm{s} 3 \#$} & Rot. zewn. & 20,7 & 8,5 & 17,7 & 8,4 & $0,0 * *$ \\
\hline & Rot. wewn. & 31,7 & 13,0 & 30,1 & 12,4 & 0,2 \\
\hline \multirow{2}{*}{$180^{\circ} / \mathrm{s} 3 \#$} & Rot. zewn. & 24,4 & 12,8 & 20,9 & 12,6 & $0,0 * *$ \\
\hline & Rot. wewn. & 37,3 & 21,7 & 34,5 & 21,2 & 0,3 \\
\hline \multirow{2}{*}{$270 \%$ s 15\# } & Rot. zewn. & 27,0 & 15,3 & 21,5 & 13,1 & $0,0 * *$ \\
\hline & Rot. wewn. & 44,0 & 26,2 & 40,1 & 22,0 & 0,2 \\
\hline \multirow{2}{*}{$360^{\circ} / \mathrm{s} 3 \#$} & Rot. zewn. & 28,6 & 16,0 & 25,1 & 15,8 & $0,0 *$ \\
\hline & Rot. wewn. & 43,5 & 26,9 & 42,6 & 26,3 & 0,8 \\
\hline
\end{tabular}

\section{Agonist-antagonist ratio}

Results of agonist-antagonist ratios were varied for dominant and non-dominant side. The agonist-antagonist ratio was greater for dominant side in all series (Tables 5 and 6).

Table 5. Results of agonist-antagonist ratio for dominant side.

\begin{tabular}{lll} 
Dominant side & Ratio & SD \\
\hline 90 & 70.2 & 13.6 \\
180 & 85.8 & 26.9 \\
270 & 78.5 & 15.5 \\
360 & 79.1 & 20.6
\end{tabular}

Stosunek reciprokalnych grup miesśniowych (agonist-antagonist ratio)

Wyniki dotyczące stosunku reciprokalnych grup mięśniowych były zróżnicowane dla strony dominującej i niedominującej. Stosunek reciprokalnych grup mięśniowych był wyższy dla strony dominującej we wszystkich seriach, bez względu na prędkość kątową (Tabele 5 i 6 ).

Tabela 5. Wyniki stosunku reciprokalnych grup mięśniowych dla strony dominującej.

\begin{tabular}{lll} 
Strona dominująca & Ratio & SD \\
\hline $\mathbf{9 0}$ & 70,2 & 13,6 \\
$\mathbf{1 8 0}$ & 85,8 & 26,9 \\
$\mathbf{2 7 0}$ & 78,5 & 15,5 \\
$\mathbf{3 6 0}$ & 79,1 & 20,6
\end{tabular}


Table 6. Results of agonist-antagonist ratio for non-dominant side.

\begin{tabular}{lll} 
Dominant side & Ratio & SD \\
\hline 90 & 68.8 & 11.3 \\
180 & 82.8 & 23.4 \\
270 & 74.8 & 18.2 \\
360 & 71.8 & 19.6
\end{tabular}

\section{Discussion}

Isokinetic evaluation is a relatively a new approach of acquiring the objective data on patient or athlete's performance. There is still much to be researched in but the amount of new reports is growing rapidly. Isokinetics' unique feature is that information about motor properties of examined person is acquired during their movements performed at a constant velocity. In order to keep the velocity at a constant rate, a force opposite to the movement direction is generated by a dynamometer.

The first reports about isokinetics come from the 1960's and 1970's when it was found that isokinetic testing would bring unbiased data about human muscular performance (Hislop and Perrine 1967; This9 tle et al. 1967; Moffroid et al. 1969; Saha 1971). The most frequently analysed pae rameters are: agonist-antagonist ratio, average power, peak torque and total work (Brown et al. 1988; Malerba et al. 1993; Ellenbecker and Mattalino 1997; Hughes et al. 1999; Biodex Multijoint System Pro).

\section{Patient's position}

We chose the seated position for our evaluation. The seated position with the arm in the scapular plane is a safe position because the joint congruence is the best (Elt lenbecker and Davies 2000). The capsular ligaments within the rotator cuff are at indirect arrangement and the work of the muscles is facilitated. That position does
Tabela 6. Wyniki stosunku reciprokalnych grup mięśniowych dla strony niedominującej.

\begin{tabular}{lll} 
Strona dominująca & Ratio & SD \\
\hline $\mathbf{9 0}$ & 68,8 & 11,3 \\
$\mathbf{1 8 0}$ & 82,8 & 23,4 \\
$\mathbf{2 7 0}$ & 74,8 & 18,2 \\
$\mathbf{3 6 0}$ & 71,8 & 19,6
\end{tabular}

\section{Dyskusja}

Ocena za pomocą parametrów izokinetycznych jest stosunkowo nowym sposobem uzyskiwania obiektywnych danych dotyczących osiągów pacjenta czy sportowca, ale ilość nowych danych szybko rośnie. Cechą charakterystyczną izokinetyki jest to, że informacje dotyczące cech motorycznych badanej osoby zbierane są w czasie rzeczywistym, podczas wykonywania przez tę osobę ruchów o stałej prędkości. Aby utrzymać stałą prędkość, przykładana jest siła o tej samej wartości, ale przeciwna do kierunku ruchu. Siłę tę generuje dynamometr.

Pierwsze doniesienia na temat izokinetyki pochodzą z lat 60-tych i 70-tych XX wieku, gdy odkryto, że ocena izokinetyczna pozwala na uzyskanie obiektywnych danych dotyczących pracy ludzkich mięśni (Hislop i Perrine 1967; Thistle i wsp. 1967; Moffroid i wsp. 1969; Saha 1971). Najczęściej analizowanymi parametrami są: stosunek reciprokalnych grup mięśniowych (agonist-antagonist ratio), średnia moc mięśni (average power), szczytowy moment siły mięśni (muscle peak torque) i całkowita praca mięśni (total work) (Brown i wsp. 1988; Malerba i wsp. 1993; Ellenbecker i Mattalino 1997; Hughes i wsp. 1999; Biodex Multijoint System Pro).

\section{Pozycja osoby badanej}

Do przeprowadzenia badań wybrana została pozycja siedząca ze stawem ramiennym w płaszczyźnie łopatki. Jest to bezpieczna pozycja, ponieważ dzięki niej możliwe jest uzyskanie maksymalnego dopasowania powierzchni stawowych (Ellenbecker i Davies 2000). Co więcej, tylne więzadła torebkowe w obrębie stożka rotatorów 
not cause a risk of injury within anatomical structures above the glenohumeral joint (Davies 1992). Neutral modified seated position allows to collect valuable data at an early stage of rehabilitation. It is safe and comfortable for post-operative patients (Ellenbecker and Derscheid 1989).

This position was also chosen because of high repetitiveness of obtained results (Knops et al. 1998). This was reported by Ellenbecker and Davies for $60 \%$ sec., $180^{\circ} / \mathrm{sec}$. and $300 \%$ sec. speeds (that is multiples of $60 \% \mathrm{sec}$.). Coefficients of correlation ranged from 0.91 to 0.96 what proves the high reliability of examinations conducted in this position (Ellenbecker and Davies 2000). Alternative lying position is more proper for assessing overhead activities than non-athletic persons' shoulder properties (Basset et al. 1990).

\section{Agonist-antagonist ratio}

One of the most important piece of data obtained in the conducted examination is the agonist-antagonist ratio in internal and external rotation. The research proved considerable value of the agonist-antagonist ratio on the dominant side for examined angular speeds.

The value of agonist-antagonist ratios for external/internal rotation proposed by BIODEX $^{\circledR}$ dynamometer's software as the model value and oscillated in the range of $66-71 \%$. It is confirmed by the result achieved by Davies (Davies 1992) and Ivey et al. (Ivey et al. 1985). The normal value for agonist/antagonist ratio calculated by Davies and Ivey et al. is 64-71\%. (Ivey układają się w pozycji pośredniej, a to ułatwia pracę mięśni. Zmniejszone jest także ryzyko urazu w obrębie struktur anatomicznych znajdujących się ponad stawem ramiennym (Davies 1992). Siedząca pozycja neutralna zmodyfikowana pozwala na uzyskanie wartościowych danych we wczesnej fazie procesu rehabilitacji. Jest ona bezpieczna i wygodna dla pacjentów pooperacyjnych, a także nie stanowi zagrożenia w większości patologii (Ellenbecker i Derscheid 1989).

Kolejnym powodem, dla którego wybrana została właśnie pozycja siedząca zmodyfikowana neutralna jest wysoka powtarzalność uzyskiwanych wyników (Knops i wsp. 1998). Zostało to potwierdzone przez Ellenbeckera i Daviesa dla prędkości kątowych $60 \%$ sek., $180 \%$ sek. i $300 \%$ sek. (tj. wielokrotności $60^{\circ} /$ sek.). Współczynniki korelacji wyniosły od 0,91 do 0,96, co dowodzi wysokiej rzetelności badań prowadzonych w tej pozycji (Ellenbecker i Davies 2000). Alternatywna pozycja leżąca jest bardziej odpowiednia dla oceny ruchów wykonywanych ponad głową u sportowców niż u osób nie uprawiających sportu (Basset i wsp. 1990).

Stosunek reciprokalnych grup mięśniowych Jednym z najważniejszych parametrów otrzymanych dzięki przeprowadzonemu badania jest stosunek reciprokalnych grup mięśniowych (stosunek agonistów-antagonistów) w ruchu rotacji wewnętrznej i zewnętrznej. Badanie dowiodło znacznie wyższą wartość stosunku reciprokalnych grup mięśniowych po stronie dominującej we wszystkich prędkościach kątowych.

Wartość stosunków reciprokalnych grup mięśniowych zaproponowana przez oprogramowanie dynamometru BIODEX ${ }^{\circledR}$ jako wartość wzorcowa oscylowała w zakresie $66-71 \%$. Potwierdzają to także wyniki osiągnięte przez Davies'a (Davies 1992) i Ivey'a i wsp. (Ivey i wsp. 1985). Typowa wartość stosunku reciprokalnych grup mięśniowych obliczona przez Davies'a i Ivey'a i wsp. 
et al. 1985; Davies 1992; Biodex Multi-joint System Pro). Our results achieved values $68.8-85.8 \%$. These results are very similar to literature norms except $180^{\circ} \mathrm{sec}$ set. The reason for minor differences in the results is probably more age-diversified group of other researchers than our group.

\section{Average power}

Similarly to the research conducted by Ellenbecker and Bleacher our examination confirmed significantly greater average power in external rotation of the dominant limb comparing to the non-dominant one (Ellenbecker and Bleacher 1999).

\section{Peak torque}

In our group, peak torque in external rotation was significantly greater on the dominant side in comparison to non-dominant side in $360 \mathrm{deg}$./sec and $270 \mathrm{deg}$./sec trials. The results of internal rotation peak torque were similar in dominant and non-dominant limb. Also they were higher than results in external rotation. The difference of peak torque values in external and internal rotation of the dominant and non-dominant limbs in most cases didn't exceed 10\% in favour of the dominant side so it is possible to assume that it was located in the normal assumed by Nirschl and Sobel (Nirschl and Sobel 1981). In the other research with patients minimum 4 years after shoulder surgery stabilization we received similar results for dominant external and internal rotation (20.8 and $30.7 \mathrm{Nm}$ ) and also for the non-dominant side (19.2 and $29.2 \mathrm{Nm}$ ) in $90 \%$ s set (Bręborowicz 2015). mieści się w granicach 64-71\% (Ivey i wsp. 1985; Davies 1992; Biodex Multi-joint System Pro). Uzyskane dzięki naszym badaniom wyniki osiągnęły wartość $68,8-85,8 \%$. Te wyniki są bardzo zbliżone do opisywanych w literaturze norm, za wyjątkiem serii z prędkością kątową wynoszącą $180^{\circ}$ sek. Powodem niewielkich różnic jest prawdopodobnie bardziej zróżnicowana wiekowo grupa kontrolna u innych naukowców.

Średnia moc mięśni (muscle average power) Podobnie, jak w badaniu przeprowadzonym przez Ellenbeckera I Bleachera, nasze badanie potwierdziło znacznie wyższą średnią moc mięśni w rotacji zewnętrznej kończyny dominującej w porównaniu z kończyną niedominującą (Ellenbecker i Bleacher 1999).

Szczytowy moment sity mięśni (muscle peak torque)

W naszej grupie osób poddanych badaniu, szczytowy moment siły mięśni w rotacji zewnętrznej był znacznie wyższy po stronie dominującej w porównaniu ze stroną niedominującą dla prób o prędkościach $360 \%$ sek. i $270^{\circ}$ sek. Wyniki szczytowego momentu siły mięśni dla rotacji wewnętrznej były podobne dla kończyny dominującej i niedominującej. Co więcej, osiągnięto wartości wyższe niż w rotacji zewnętrznej. Różnica wartości szczytowego momentu siły mięśni pomiędzy rotacją wewnętrzną i zewnętrzną kończyny dominującej i niedominującej w większości przypadków nie przekroczyła 10\% na korzyść strony dominującej, więc można przyjąć założenie, że uzyskane parametry mieściły się w normie określonej przez Nirschla i Sobela (Nirschl i Sobel 1981). W porównaniu do innego badania dotyczącego pacjentów minimum 4 lata po operacyjnej stabilizacji barku uzyskaliśmy podobne wyniki dla rotacji zewnętrznej i wewnętrznej kończyny dominującej (20,8 i 30,7 Nm), jak również dla kończyny niedominującej (19,2 i 29,2 Nm) dla próby o prędkości kątowej wynoszącej $90 \%$ sek. (Bręborowicz 2015). 
Total work

Total work values were compared to those received by Malerba et al. (Malerba et al. 1993). Total work values were similar in spite of different angular speeds (the difference in speeds was $30 \% \mathrm{sec}$.). In Malerba's examination there were 5 repetitions, that is 2 more than in our examination (Malerba et al. 1993). For the dominant limb, the average result in external rotation acquired by Malerba was $76 \mathrm{~J}$ for recalled speeds is close to ours (72 J). For the dominant limb in internal rotation Malerba received $194 \mathrm{~J}$ and our group received $113 \mathrm{~J}$.

\section{Conclusions}

1. The dominant extremity's peak torque is higher than the non-dominant one's and it is always higher for internal rotators; the average power and total work values in external rotation are always higher in the dominant extremity in comparison to the non-dominant extremity.

2. Agonist-antagonist ratio of internal to external rotators oscillates within the range of $68.8-85.8 \%$ and is higher in the dominant extremity

3. The results could be useful for further research as auxiliary data for normative data concerning healthy shoulders of nonathletes.
Całkowita praca (total work)

Rezultaty całkowitej pracy mięśni porównano z wynikami osiągniętymi przez Malerbę i wsp. (Malerba i wsp. 1993). Osiagnięte wyniki były podobne pomimo różnych prędkości kątowych (różnica w prędkościach wynosiła $30^{\circ}$ sek.). W badaniu Malerby badani wykonywali 5 powtórzeń, czyli o 2 więcej niż w naszym badaniu (Malerba i wsp. 1993). Dla strony dominującej, średnia wartość uzyskana w rotacji zewnętrznej dla wspomnianych prędkości wyniosła $76 \mathrm{~J}$, co jest wynikiem bliskim naszemu (72 J). Dla rotacji wewnętrznej kończyny dominującej Malerba uzyskał $194 \mathrm{~J}$, natomiast nasi ochotnicy $113 \mathrm{~J}$.

\section{Wnioski}

1. Szczytowy moment siły mięśni strony dominującej jest wyższy niż strony niedominującej i jest on zawsze wyższy dla rotatorów wewnętrznych; wartość średniej mocy i całkowitej pracy mięśni w rotacji zewnętrznej są zawsze większe po stronie dominującej w porównaniu ze stroną niedominującą.

2. Stosunek reciprokalnych grup mięśniowych rotatorów wewnętrznych i zewnętrznych oscylował w granicach 68,8-85,8\% i był wyższy dla kończyny dominującej.

3. Wyniki mogą być użyteczne z punktu widzenia dalszych badań, jako dane uzupełniające dla danych normatywnych dotyczących zdrowych stawów ramiennych osób nie uprawiających sportu wyczynowego. 


\section{REFERENCES}

Alderink, G. J., Kuck, D. J. (1986) 'Isokinetic Shoulder Strength of High School and College-Aged Pitchers*.' Journal of Orthopaedic \& Sports Physical Therapy, 7(4), pp. 163-172.

Bassett, R. W., Browne, A. O., Morrey, B. F., An, K. N. (1990) 'Glenohumeral muscle force and moment mechanics in a position of shoulder instability.' Journal of Biomechanics, 23(5), pp. 405-415.

Biodex Multi Joint System Pro Setup/ Operation Manual,850-000 FN: 08-262 Rev A 4/11.

Biodex Multi-Joint System. 'Isokinetic testing and data interpretation/normative database.'Biodex Medical Systems, Inc.

Bręborowicz, E. 'Evaluation of selected biomechanical parameters in shoulder stabilization surgery', Ph.D. dissertation, Poznan University of Medical Sciences, Poznań 2015. Brown, L. P., Niehues, S. L., Harrah, A., Yavorsky, P., Hirshman, H. P. (1988) 'Upper extremity range of motion and isokinetic strength of the internal and external shoulder rotators in major league baseball players.' The American Journal of Sports Medicine, 16(6), pp. 577-585.

Chandler, T. J., Kibler, W. B., Stracener, E. C., Ziegler, A. K., Pace, B. (1992) 'Shoulder strength, power, and endurance in college tennis players.' The American Journal of Sports Medicine, 20(4), pp. 455-458.

Cook, E. E., Gray, V. L., Savinar-Nogue, E., Medeiros, J. (1987) 'Shoulder antagonistic strength ratios: a comparison between college-level baseball pitchers and nonpitchers.' Journal of Orthopaedic \& Sports Physical Therapy, 8(9), pp. 451-461.

Davies, G. J. (1992) 'A compendium of isokinetics in clinical usage and rehabilitation techniques.' S\&S Publishers.

Eliasz, J., Gajewski, J., Janiak, J., Trzaskoma, Z., Wit, A. (1994) 'Przejawy sity mięśniowej - warunki i zasady jej pomiarów oraz znaczenie dla praktyki treningowej.' Teoria treningu, Sport Wyczynowy, (5-6), 2 pp. 3-25.

\section{PIŚMIENNICTWO}

Alderink, G. J., Kuck, D. J. (1986) 'Isokinetic Shoulder Strength of High School and College-Aged Pitchers*' Journal of Orthopaedic \& Sports Physical Therapy, 7(4), pp. 163-172.

Bassett, R. W., Browne, A. O., Morrey, B. F., An, K. N. (1990) 'Glenohumeral muscle force and moment mechanics in a position of shoulder instability.' Journal of Biomechanics, 23(5), pp. 405-415.

Biodex Multi Joint System Pro Setup/ Operation Manual,850-000 FN: 08-262 Rev A 4/11.

Biodex Multi-Joint System. 'Isokinetic testing and data interpretation/normative database.'Biodex Medical Systems, Inc.

Bręborowicz, E. 'Evaluation of selected biomechanical parameters in shoulder stabilization surgery', Ph.D. dissertation, Poznan University of Medical Sciences, Poznań 2015. Brown, L. P., Niehues, S. L., Harrah, A., Yavorsky, P., Hirshman, H. P. (1988) 'Upper extremity range of motion and isokinetic strength of the internal and external shoulder rotators in major league baseball players.' The American Journal of Sports Medicine, 16(6), pp. 577-585.

Chandler, T. J., Kibler, W. B., Stracener, E. C., Ziegler, A. K., Pace, B. (1992) 'Shoulder strength, power, and endurance in college tennis players.' The American Journal of Sports Medicine, 20(4), pp. 455-458.

Cook, E. E., Gray, V. L., Savinar-Nogue, E., Medeiros, J. (1987) 'Shoulder antagonistic strength ratios: a comparison between college-level baseball pitchers and nonpitchers.' Journal of Orthopaedic \& Sports Physical Therapy, 8(9), pp. 451-461.

Davies, G. J. (1992) 'A compendium of isokinetics in clinical usage and rehabilitation techniques.' S\&S Publishers.

Eliasz, J., Gajewski, J., Janiak, J., Trzaskoma, Z., Wit, A. (1994) 'Przejawy sity mięśniowej - warunki i zasady jej pomiarów oraz znaczenie dla praktyki treningowej.' Teoria treningu, Sport Wyczynowy, (5-6), 2 pp. 3-25. 
Ellenbecker, T. S., Bleacher, J. (1999) 'A descriptive profile of bilateral glenohumeral joint internal and external rotation strength in uninjured females using the Cybex NORM dynamometer.' Physical Theapy, 79(5), pp. S80. Ellenbecker, T. S., Derscheid, G. L. (1989) 'Rehabilitation of overuse injuries of the shoulder.' Clinics in Sports Medicine, 8(3), pp. 583-604.

Ellenbecker, T. S., Mattalino, A. J. (1997) 'Concentric isokinetic shoulder internal and external rotation strength in professional baseball pitchers.' Journal of Orthopaedic \& Sports Physical Therapy, 25(5), pp. 323-328. Ellenbecker, T. S. (1991) 'A total arm strength isokinetic profile of highly skilled tennis players.' Isokinetics and Exercise Science, 1(1), pp. 9-21.

Ellenbeckert, T. S. (1992). Shoulder internal and external rotation strength and range of motion of highly skilled junior tennis players. Isokinetics and Exercise Science, 2(2), pp. 65-72.

Ellenbecker, T. S., Davies, G. J. (2000) 'The application of isokinetics in testing and rehabilitation of the shoulder complex.' Journal of Athletic Training, 35(3), pp. 338-350. Hinton, R. Y. (1988) 'Isokinetic evaluation of shoulder rotational strength in high school baseball pitchers.' The American Journal of Sports Medicine, 16(3), pp. 274-279.

Hislop, H. J., Perrine, J. J. (1967) 'The isokinetic concept of exercise.' Physical Therapy, 47(2), pp. 114-117.

Hughes, R. E., Johnson, M. E., O'Driscoll, S. W., An, K. N. (1999) 'Normative values of agonist-antagonist shoulder strength ratios of adults aged 20 to 78 years.' Archives of Physical Medicine and Rehabilitation, 80(10), pp. 1324-1326.

Ivey Jr, F. M., Calhoun, J. H., Rusche, K., Bierschenk, J. (1985) 'Isokinetic testing of shoulder strength: normal values.' Archives of Physical Medicine and Rehabilitation, 66(6), pp. 384-386.

Knops, J. E., Meiners, T. K., Davies, G. J., Elfessi, A. M. (1998). Isokinetic test-retest reliability of the modified neutral shoulder test
Ellenbecker, T. S., Bleacher, J. (1999) 'A descriptive profile of bilateral glenohumeral joint internal and external rotation strength in uninjured females using the Cybex NORM dynamometer.' Physical Theapy, 79(5), pp. S80. Ellenbecker, T. S., Derscheid, G. L. (1989) 'Rehabilitation of overuse injuries of the shoulder.' Clinics in Sports Medicine, 8(3), pp. 583-604.

Ellenbecker, T. S., Mattalino, A. J. (1997) 'Concentric isokinetic shoulder internal and external rotation strength in professional baseball pitchers.' Journal of Orthopaedic \& Sports Physical Therapy, 25(5), pp. 323-328. Ellenbecker, T. S. (1991) A total arm strength isokinetic profile of highly skilled tennis players.' Isokinetics and Exercise Science, 1(1), pp. 9-21.

Ellenbeckert, T. S. (1992). Shoulder internal and external rotation strength and range of motion of highly skilled junior tennis players. Isokinetics and Exercise Science, 2(2), pp. 65-72.

Ellenbecker, T. S., Davies, G. J. (2000) 'The application of isokinetics in testing and rehabilitation of the shoulder complex.' Journal of athletic training, 35(3), pp. 338-350. Hinton, R. Y. (1988) 'Isokinetic evaluation of shoulder rotational strength in high school baseball pitchers.' The American Journal of Sports Medicine, 16(3), pp. 274-279.

Hislop, H. J., Perrine, J. J. (1967) 'The isokinetic concept of exercise.' Physical Therapy, 47(2), pp. 114-117.

Hughes, R. E., Johnson, M. E., O'Driscoll, S. W., An, K. N. (1999) 'Normative values of agonist-antagonist shoulder strength ratios of adults aged 20 to 78 years.' Archives of Physical Medicine and Rehabilitation, 80(10), pp. 1324-1326.

Ivey Jr, F. M., Calhoun, J. H., Rusche, K., Bierschenk, J. (1985) 'Isokinetic testing of shoulder strength: normal values.' Archives of Physical Medicine and Rehabilitation, 66(6), pp. 384-386.

Knops, J. E., Meiners, T. K., Davies, G. J., Elfessi, A. M. (1998). Isokinetic test-retest reliability of the modified neutral shoulder test 
position. Journal of Orthopaedic \& Sports Physical Therapy.

Malerba, J. L., Adam, M. L., Harris, B. A., Krebs, D. E. (1993) 'Reliability of dynamic and isometric testing of shoulder external and internal rotators.' Journal of Orthopaedic \& Sports Physical Therapy, 18(4), pp. 543-552. Moffroid, M., Whipple, R., Hofkosh, J., Lowman, E., Thistle, H. (1969) 'A study of isokinetic exercise.' Physical Therapy, 49(7), pp. 735-747.

Nirschl, R. P., Sobel, J. (1981). Conservative treatment of tennis elbow.' The Physician and Sportsmedicine, 9, pp. 43-54.

Quincy, R. I., Davies, G. J., Kolbeck, K. J., Szymanski, J. L. (2000) 'Isokinetic exercise: the effects of training specificity on shoulder strength development.' Journal of Athletic Training, 35 (suppl 2), pp. S64.

Saha, A. K. (1971) 'Dynamic stability of the glenohumeral joint.' Acta Orthopaedica Scandinavica, 42(6), pp. 491-505.

Thistle, H. G., Hislop, H. J., Moffroid, M., Lowman, E. W. (1967) 'Isokinetic contraction: a new concept of resistive exercise.' Archives of Physical Medicine and Rehabilitation, 48(6), pp. 279-282.

Wilk, K. E., Andrews, J. R., Arrigo, C. A., Keirns, M. A., Erber, D. J. (1993) 'The strength characteristics of internal and external rotator muscles in professional baseball pitchers.' The American Journal of Sports Medicine, 21(1), pp. 61-66.

Authors reported no source of funding. Authors declared no conflict of interest.

Author responsible for correspondence:

Przybyła Jakub

Department and Clinic of Orthopaedics, Traumatology and Hand Surgery, Poznan University of Medical Sciences

28 Czerwca 1956 No 135/147

61-545 Poznan, Poland

przybylak@gmail.com

+48501966255 position. Journal of Orthopaedic \& Sports Physical Therapy.

Malerba, J. L., Adam, M. L., Harris, B. A., Krebs, D. E. (1993) 'Reliability of dynamic and isometric testing of shoulder external and internal rotators.' Journal of Orthopaedic \& Sports Physical Therapy, 18(4), pp. 543-552. Moffroid, M., Whipple, R., Hofkosh, J., Lowman, E., Thistle, H. (1969) 'A study of isokinetic exercise.' Physical Therapy, 49(7), pp. 735-747.

Nirschl, R. P., Sobel, J. (1981). Conservative treatment of tennis elbow.' The Physician and Sportsmedicine, 9, pp. 43-54.

Quincy, R. I., Davies, G. J., Kolbeck, K. J., Szymanski, J. L. (2000) 'Isokinetic exercise: the effects of training specificity on shoulder strength development.' Journal of Athletic Training, 35 (suppl 2), pp. S64.

Saha, A. K. (1971) 'Dynamic stability of the glenohumeral joint.' Acta Orthopaedica Scandinavica, 42(6), pp. 491-505.

Thistle, H. G., Hislop, H. J., Moffroid, M., Lowman, E. W. (1967) 'Isokinetic contraction: a new concept of resistive exercise.' Archives of Physical Medicine and Rehabilitation, 48(6), pp. 279-282.

Wilk, K. E., Andrews, J. R., Arrigo, C. A., Keirns, M. A., Erber, D. J. (1993) 'The strength characteristics of internal and external rotator muscles in professional baseball pitchers.' The American Journal of Sports Medicine, 21(1), pp. 61-66.

Autorzy nie zgłosili źródła finansowania. Autorzy nie deklarowali konfliktu interesów.

Autor odpowiedzialny za korespondencje: Przybyła Jakub

Katedra i Klinika Ortopedii, Traumatologii i Chirurgii Ręki Uniwersytetu Medycznego w Poznaniu

ul. 28 Czerwca 1956 135/147

61-545 Poznań, Polska

przybylak@gmail.com

+48501966255 